\title{
Nitrogen in Insects: Implications for Trophic Complexity and Species Diversification
}

\author{
William F. Fagan, ${ }^{1, *}$ Evan Siemann, ${ }^{2}$ Charles Mitter, ${ }^{3}$ Robert F. Denno, ${ }^{3}$ Andrea F. Huberty, ${ }^{3}$ \\ H. Arthur Woods, ${ }^{1, \dagger}$ and James J. Elser ${ }^{1}$
}

1. Department of Biology, Arizona State University, Tempe, Arizona 85287;

2. Department of Ecology and Evolutionary Biology, Rice

University, Houston, Texas 77005;

3. Department of Entomology, University of Maryland, College

Park, Maryland 20742

Submitted October 11, 2001; Accepted May 24, 2002

AвSTRACT: Disparities in nutrient content (nitrogen and phosphorus) between herbivores and their plant resources have lately proven to have major consequences for herbivore success, consumer-driven nutrient cycling, and the fate of primary production in ecosystems. Here we extend these findings by examining patterns of nutrient content between animals at higher trophic levels, specifically between insect herbivores and predators. Using a recently compiled database on insect nutrient content, we found that predators exhibit on average $15 \%$ greater nitrogen content than herbivores. This difference persists after accounting for variation from phylogeny and allometry. Among herbivorous insects, we also found evidence that recently derived lineages (e.g., herbivorous Diptera and Lepidoptera) have, on a relative basis, $15 \%-25 \%$ less body nitrogen than more ancient herbivore lineages (e.g., herbivorous Orthoptera and Hemiptera). We elaborate several testable hypotheses for the origin of differences in nitrogen content between trophic levels and among phylogenetic lineages. For example, interspecific variation in insect nitrogen content may be directly traceable to differences in dietary nitrogen (including dilution by gut contents), selected for directly in response to the differential scarcity of dietary nitrogen, or an indirect consequence of adaptation to different feeding habits. From some functional perspectives, the magnitude rather than the source of the interspecific differences in nitrogen content may be most critical. We conclude by discussing the implications of the observed patterns for both the trophic complexity of food webs and the evolutionary radiation of herbivorous insects.

* Corresponding author. Present address: Department of Biology, University of Maryland, College Park, Maryland 20742; e-mail: bfagan@glue.umd.edu.

${ }^{\dagger}$ Present address: School of Biological Sciences, University of Texas, Austin, Texas 78712 .

Am. Nat. 2002. Vol. 160, pp. 784-802. (c) 2002 by The University of Chicago. 0003-0147/2002/16006-010363\$15.00. All rights reserved.
Keywords: allometry, food web dynamics, nutrient content, insect phylogeny, diversification of herbivorous insects, dietary nitrogen.

The mismatch in nitrogen content between phytophagous insects and their host plants has been recognized for years as a critical factor influencing herbivore success (Slansky and Feeny 1977; McNeill and Southwood 1978; Mattson 1980; Denno and McClure 1983; Strong et al. 1984; White 1993). The importance of unbalanced elemental composition between autotrophs and herbivores is also now recognized for aquatic systems (Sterner and Schulz 1998; Elser et al. 2000b). Stoichiometric imbalance at the base of food webs appears to strongly affect herbivore success (Fox and Macauley 1977; Sterner and Schulz 1998), consumerdriven nutrient cycling (Pastor et al. 1988; Moen et al. 1998; Elser and Urabe 1999), and the fate of primary production in ecosystems (Cebrian 1999). These wide-ranging impacts suggest that it is important to understand better, from both ecological and evolutionary perspectives, the mechanisms underlying variation in the nutrient content of organisms across trophic levels in a diversity of food webs (Sterner and Elser 2002). In this article, we analyze the distribution of one critical nutrient, nitrogen, across a wide range of herbivorous and predaceous insect species.

On average, the nitrogen $(\mathrm{N})$ and phosphorus $(\mathrm{P})$ contents (expressed as a percentage of dry biomass) of autotrophs (vascular plant foliage, algae) are 10-20 times lower than those of typical herbivores (McNeill and Southwood 1978; Mattson 1980; Elser et al. 2000b). Because of the long history of research in plant nutrition, foliar $\mathrm{N}$ content is known to vary with plant- and environmentrelated parameters like plant taxon, tissue, growth form and size (Mattson 1980; Strong et al. 1984; Nielsen et al. 1996), soil nutrients (Marschner 1995), light intensity (Greenwood 1976), and atmospheric $\mathrm{CO}_{2}$ (Curtis and Wang 1998).

Much less is known about the biological determinants of the nutrient content of metazoan consumer taxa. At the physiological level, herbivorous insects maintain a relatively tight homeostasis in body elemental composition 
(Fox and Macauley 1977; Slansky and Feeny 1977). For example, cabbage butterfly larvae fed low-N plants consumed food faster and utilized $\mathrm{N}$ more efficiently than larvae fed high-N plants (Slansky and Feeny 1977). As a result, rates of growth and $\mathrm{N}$ accumulation were as high on plants containing $1.5 \% \mathrm{~N}$ (dry wt) as they were on plants with $4.8 \%$ N. Similarly, for the aquatic crustacean Daphnia, body $\mathrm{N}$ and $\mathrm{P}$ contents changed little when animals were fed nutrient-rich food or were starved (Andersen and Hessen 1991). However, more recent data indicate that aquatic herbivores may not maintain an entirely strict homeostasis in which body elemental composition shows no change in response to variation in food nutrient content. For instance, in another study of $\mathrm{C}$ and $\mathrm{P}$ balance in Daphnia, body $\mathrm{P}$ content declined, but only modestly (by $\sim 20 \%-30 \%$ ), when animals were fed diets with greatly reduced (20-fold lower) P content (DeMott et al. 1998). The general view that has emerged from studies of phytophagous insects and aquatic herbivores is that individual animals actively regulate body elemental composition but that this regulation may not produce strict homeostasis (Elser et al. 2000b; Sterner and Elser 2002).

Among-taxa variation in nutrient content is especially poorly understood. In a recent survey (Elser et al. 2000b), body $\mathrm{N}$ and $\mathrm{P}$ contents of herbivorous insects, like those of crustacean zooplankton, were shown to vary threefold and eightfold, respectively, across taxa. However, the ecological and evolutionary determinants of such variation are not known. For example, we know little about the dependence of animal nutrient content on trophic level. In lakes (Sterner and Elser 2002), P content appears to increase consistently from autotrophs (P-limited phytoplankton) to herbivores (crustacean zooplankton) to planktivorous predators (fishes). Nothing is known, however, about the relationship between trophic position and nutrient content in insect communities.

The rates and correlates of evolutionary change in animal elemental composition are also little examined. Essentially, the only hypothesis that has been critically examined involves the link between body $\mathrm{P}$ content and growth rate in crustacean zooplankton (the "growth rate hypothesis"; Elser et al. 1996, 2000a; Vrede et al. 1998). Other nutrients, animal groups, and questions remain unexamined. For example, the relationship of nutrient content with life-history features such as body size or dispersal ability is unknown. A fundamental issue is that we do not know how readily body elemental composition can be altered by natural selection. One might expect use of a nutrient-poor food source to select for lowered body content of - and hence requirement for-the limiting nutrient (Markow et al. 1999; BaudouinCornu et al. 2001). For example, we might expect herbivorous insects to evolve lowered $\mathrm{N}$ content when consuming plant material with severely low N content. Alternatively, total body elemental composition may reflect so many independent features of biochemistry or body plan that phylogenetic constraints thwart adaptation to differences in nutrient availability.

In this article, we analyze the data set compiled by Elser et al. $(2000 b)$, supplemented with additional data gathered since then, to evaluate the contributions of several ecological and evolutionary factors (trophic level, feeding style, body size, and phylogeny) to variation in the body $\mathrm{N}$ content of terrestrial insects. To our knowledge, this is the first analysis of its kind. The analysis reveals marked differences in $\mathrm{N}$ content between trophic levels (herbivores vs. predators) and among major phylogenetic lineages. The patterns appear robust to possible contributions of allometry and ontogeny. We outline several hypotheses for the source of the patterns of $\mathrm{N}$ content and discuss their possible significance for the structure of food webs and the evolution of insect herbivores and predators. Regardless of its mechanistic underpinnings, the interspecific variation in insect nitrogen content that we report may be important from functional perspectives, in that insects may constitute strikingly heterogeneous packets of nutrients for their consumers or decomposers.

\section{Methods \\ The Data Set}

Data for the $\mathrm{N}$ content of terrestrial insects (143 species), aquatic insects (nine species), and spiders (two species) were compiled from 31 published and unpublished sources. We use the term "percent $\mathrm{N}$ content" to describe $\mathrm{N}$ content as a percent of dry body mass. In all, $\mathrm{N}$ data were available for 152 species of insects distributed in 131 genera, 65 families, and nine orders (Ephemeroptera, Odonata, Orthoptera, Mantodea, Hemiptera, Coleoptera, Hymenoptera, Diptera, and Lepidoptera). Nitrogen data were also obtained for two spider species in two separate families. When multiple observations were available for a single species, they were averaged before analysis. This procedure reduced the total number of measurements (334) down to 154, the total species count. In addition, data on trophic position (herbivore vs. predator/parasitoid), developmental stage (adult vs. nymph or larva), adult body length $(\mathrm{mm})$, and taxonomy were scored for each species. Insects were sorted into trophic groups, resulting in 119 species of herbivores and 33 species of predators/parasitoids. With one exception, four species of neoconocephaline grasshoppers (Orthoptera: Tettigoniidae), omnivores (e.g., crickets and cockroaches) were excluded from our analysis. We scored these omnivorous grasshoppers as predators because, although they may feed substantially on plant tissue, existing data 
suggest that they cannot complete development in the absence of animal prey (R. F. Denno, unpublished data). A complete summary of the data set, including original citations, can be obtained on the web at http:// www.nceas.ucsb.edu/ecostoichiometry.

\section{Nitrogen Content across Trophic Levels}

One of our central aims was to test the hypothesis that insect $\mathrm{N}$ content is a function of trophic position. Given the well-known increase in $\mathrm{N}$ content from autotrophs to herbivores (e.g., McNeill and Southwood 1978), we postulated that $\mathrm{N}$ content would also increase in the step from herbivores to predators. To test this hypothesis, we must distinguish the influence of trophic level on among-species variation in $\mathrm{N}$ content from the potential influence of body size. We also must account for variation in $\mathrm{N}$ content stemming from unspecified differences correlated with phylogeny for two reasons. If either trophic level or $\mathrm{N}$ content are significantly conserved during phylogenesis, treating species' values as independent data points would overestimate the degrees of freedom available for testing the association of $\mathrm{N}$ content with trophic level per se (Felsenstein 1985). Conversely, failure to correct for phylogeny could obscure an actual correlation with trophic level (Harvey and Pagel 1991).

Trophic level is strongly conserved among insects, with members of many genera, families, and sometimes orders all inhabiting the same trophic level (Southwood 1973; Strong et al. 1984). Phylogenetic patterns in N content are heretofore unstudied among insects. Our initial mappings of $\mathrm{N}$ content onto cladograms suggested some conservation of nutrient content within clades consisting entirely of herbivores or predators. For example, within the acridid grasshoppers, a strictly phytophagous group, $\mathrm{N}$ contents for the genus Melanoplus (seven species represented) are all above $10 \%$ (mean $=11.40 \%)$, while those in Schistocerca (three species) are all below $10 \%$ (mean $=9.31 \%$ ). However, $\mathrm{N}$ content appears much more evolutionarily variable than trophic level, and our subsequent analyses (see "For Herbivores, Nitrogen Content Varies among Major Insect Lineages") suggest that it evolves within relatively loose phylogenetic constraints.

We used three approaches to account for possible phylogenetic nonindependence among species' $\mathrm{N}$ content values while testing for differences between trophic levels. All methods were based on the principle of phylogenetically independent contrasts (Felsenstein 1985) but represent different points on the spectrum of trade-offs between stringency of correction for similarity of $\mathrm{N}$ content due to common ancestry and potential statistical power (Mazer 1998; Ackerly 1999). Exploration of this range of trade- offs was motivated by the apparent weakness of phylogenetic conservation of $\mathrm{N}$ content.

The first analysis partitioned species into a set of ordinal-level groups, each containing at least one phylogenetically independent contrast between herbivores and predators. These groupings corresponded to a single order in the case of Hemiptera, Coleoptera, and Hymenoptera, all of which were represented in our data set by both herbivores and predators. Orders represented by only one trophic level in our database were combined with all or part of a phylogenetically adjacent order, following the phylogeny of Kristensen (1991; see also Wheeler et al. 2001), to achieve contrasts. Specifically, we combined the exemplars of Ephemeroptera and Odonata into the contrast group Palaeoptera, Mantodea and Orthoptera to form the contrast group Lower Neoptera, and Lepidoptera and Diptera to form the contrast group Panorpida.

We then performed ANOVAs to test for differences in $\mathrm{N}$ content between herbivores and predators (trophic level) while controlling for contributions from ordinal grouping as defined above and from adult size ( $\log _{10}$-transformed body length measured in millimeters). First, we performed a simple two-way factorial ANCOVA with trophic level and ordinal grouping as factors and body length as a numerical covariate. As alternative analyses, we used general linear modeling to conduct a series of sequential ANCOVAs in which we first accounted for variation attributable to allometric and/or phylogenetic sources. In each case, we then used the residuals from the first step as the dependent variable in a second step, in which one or more factors, but always trophic level, appeared. Such sequential ANCOVAs treat trophic level more severely than the preceding twoway ANCOVA because they give complete priority to the model terms appearing in the first step, leaving only the variance unexplained from that ANCOVA for use in the step involving trophic level. We explored 2 different sequential ANCOVA models. The first was as follows: step 1: ordinal grouping, step 2: trophic level + body length; the second, step 1: ordinal grouping + body length, step 2: trophic level. In all cases, percent $\mathrm{N}(\% \mathrm{~N})$ data were subjected to angular transformation before analyses.

The foregoing analyses correct for mean differences in $\% \mathrm{~N}$ among ordinal-level groupings but treat species' values within these groupings as independent. Our second approach to correcting for phylogeny focused instead on conservatism at the level of insect families. To do this, we reduced the data set to a single median $\% \mathrm{~N}$ and body length value for each family and then repeated the sequence of factorial and sequential ANCOVAs described above. This analysis corrects for differences among families but ignores any phylogenetic conservatism above or below this level.

Our third approach accounted for the phylogenetic contribution to species' similarities at all levels by assembling 
a composite phylogeny from the recent literature that resolves relationships among all the species represented to the finest level possible. The sources for this tree are given in table 1. The full tree, with $\% \mathrm{~N}$ values and trophic habits superimposed, can be viewed at http://www.nceas.ucsb.edu/ ecostoichiometry. To identify contrasts, we estimated the locations of evolutionary shifts in trophic level on the composite phylogeny using parsimony optimization. The tree was then divided into a maximal number of nonoverlapping contrast regions, each consisting of a set of contiguous branches within one of which lay an inferred change in trophic level. When multiple definitions of a given contrast were possible, we tried to pick the ones that resulted in comparisons lying within and/or between named, wellsupported clades. Experimentation with alternative contrast definitions yielded little effect on the results.

The 13 contrasts thus identified are listed in table 1. As in previous analyses, trophic level was treated as a predictor variable. To obtain a single measure of the evolutionary response in $\mathrm{N}$ content for each contrast in trophic level, the median $\% \mathrm{~N}$ for herbivore species was subtracted from the median for predators, yielding the measure $\Delta \% \mathrm{~N}(\mathrm{P}-\mathrm{H})$. To take account of the potentially confounding influence of body size, we calculated a corresponding difference in median body length between predators and herbivores for each contrast, denoted $\Delta$ body length $(\mathrm{P}-\mathrm{H})$.

Additional analyses attempted to control for several potential artifacts of data or analysis. We reran the above analyses using \%N itself rather than its angular transform. We also completely repeated our analyses after eliminating the nine freshwater insects in the database to determine the effect of restricting consideration to terrestrial species. This latter group of analyses completely eliminated the ordinal group Palaeoptera.

\section{Phylogenetic Conservation of Nitrogen Content among Herbivores}

To understand variation in $\mathrm{N}$ content, it would be useful to characterize its intrinsic degree of evolutionary conservation, independent of its correlation with hypothesized selective factors such as trophic levels. We used two different types of analyses to assess the taxonomic scale, if any, over which $\% \mathrm{~N}$ showed significant correlation with phylogeny. These analyses were restricted to herbivores, which comprised nearly $80 \%$ of our database. First, to test for correlation with phylogeny at a broad scale, we recast the first analyses described earlier using our "ordinal groupings" as a predictive variable rather than merely controlling for their possible influence. We performed two standard ANCOVAs and a sequential ANCOVA. We used two ANCOVA models: ordinal grouping + body length and ordinal grouping + body length + ordinal grouping $\times$ body length. The model for the sequential ANCOVA was as follows: step 1: body length, step 2: ordinal grouping. We used all three models on both the species-level and the family-level data

Table 1: Composition of independent contrasts within database of insect nitrogen content

\begin{tabular}{|c|c|c|c|}
\hline Ordinal group and predator taxa & Herbivore taxa & $\begin{array}{c}\text { Number of } \\
\text { predators in } \\
\text { contrast }\end{array}$ & $\begin{array}{c}\text { Number of } \\
\text { herbivores in } \\
\text { contrast }\end{array}$ \\
\hline \multicolumn{4}{|l|}{ Paleoptera: } \\
\hline Odonata & Ephemeroptera & 2 & 3 \\
\hline \multicolumn{4}{|l|}{ Lower Neoptera: } \\
\hline Conocephalini & Scudderia & 4 & 1 \\
\hline Mantidae & Acrididae & 1 & 23 \\
\hline \multicolumn{4}{|l|}{ Hemiptera: } \\
\hline Geocoris & Ligyrocoris & 1 & 1 \\
\hline Nabidae & Miridae & 2 & 6 \\
\hline Reduviidae & Other Pentatomomorpha & 2 & 6 \\
\hline Nepidae & Homoptera & 1 & 25 \\
\hline \multicolumn{4}{|l|}{ Coleoptera: } \\
\hline Coccinellidae & Other Cucujiformes & 2 & 8 \\
\hline Lycidae & Buprestidae + Elateridae & 1 & 2 \\
\hline Adephaga & Scarabaeidae & 3 & 2 \\
\hline \multicolumn{4}{|l|}{ Hymenoptera: } \\
\hline Apocrita & Symphyta & 6 & 3 \\
\hline \multicolumn{4}{|l|}{ Panorpida: } \\
\hline Lower Brachycera & Bibionidae + Lepidoptera & 5 & 30 \\
\hline Tachinidae + Syrphidae + Chamaemyidae & Chloropidae + Drosophilidae & 3 & 9 \\
\hline
\end{tabular}


sets to determine whether differences among families might be the source of any broader-scale pattern detected.

Second, to search for phylogenetic pattern at a much finer scale, we mapped $\% \mathrm{~N}$ onto recent phylogenies for the insect orders for which our database included at least 10 herbivore species. The significance of correlation with phylogeny was assessed using the PTP permutation test of Faith and Cranston (1991), as implemented in PAUP ${ }^{\star} 4.0 \mathrm{~b} 8$ (Swofford 2001). Each test was based on 500 permutations of the character state distribution across species. For each group we used an ordered, integer coding obtained by dividing the range of $\% \mathrm{~N}$ values, both on the original scale and after angular transformation, into 10 equal intervals. We did this because PAUP does not allow for continuous coding, and 10 is the largest number of ordered states it conveniently accommodates. Table 2 outlines the groups examined.

As a check on the sensitivity of PTP analyses for $\% \mathrm{~N}$ given our relatively small data set, we also tested for correlation of trophic level with phylogeny within the three groups for which we had substantial numbers of both predators and herbivores (i.e., Hemiptera, Coleoptera, Diptera). To test the possibility that advanced members of the large phytophagous clade Lepidoptera might have lower $\mathrm{N}$ than primitive ones (see "Discussion"), we tested the difference between the three recorded representatives of the more primitive lineages of Ditrysia and the 26 members of the advanced clade Obtectomera/Macrolepidoptera (Kristensen and Skalski 1999) using the permutationbased Mann-Whitney U-test (Sokal and Rohlf 1995).

\section{Influences of Gut Contents and Life Stages}

We also addressed the possibility that the nutrient content of food material in insect guts could influence whole-body
$\mathrm{N}$-in particular, that the low $\mathrm{N}$ content of terrestrial foliage (Elser et al. 2000b) may disproportionately dilute estimates of the whole body $\mathrm{N}$ content of herbivorous species relative to predaceous species. We also considered whether dilution by gut contents could lead to patterns among herbivore taxa. To explore these issues, we obtained $\% \mathrm{~N}$ data for adult acridid grasshoppers Orphulella pellidna and late instar caterpillars of the sphingid moth Manduca sexta. Dry weight and N content were recorded separately for well-fed and intact specimens, gutted specimens, gut contents, and feces. These data yielded estimates of gut content mass as a percentage of total body mass and the percentage by which $\mathrm{N}$-poor gut contents could dilute estimates of whole body $\mathrm{N}$ content. In addition, we used these data to quantitatively evaluate the extent to which extreme differences in the $\mathrm{N}$ content of these insects' diets could account for observed interspecific differences in $\mathrm{N}$ content. We supplemented these laboratory studies with literature searches to identify broader patterns in the contribution of gut material to total dry mass.

The final factor we explored was the potential influence of developmental stage on patterns of herbivore $\mathrm{N}$ content. In particular, we were concerned that differences among lineages might be influenced spuriously by the relative dominance of different life stages within different insect orders in the database. For example, orthopteran data were predominantly from adult insects, whereas lepidopteran data were predominantly from larvae. We addressed this issue in several ways. First, we restricted the database to those records arising from adult terrestrial insects and redid the species-level and family-level ANCOVAs outlined above to test for effects of trophic level and ordinal grouping (available data restricted this to four ordinal groupings only). Second, we reincluded records from immature spec-

Table 2: Herbivore taxa analyzed for fine-scale phylogenetic patterns in nitrogen content

\begin{tabular}{|c|c|c|}
\hline Taxon & References & $\begin{array}{l}\text { Number of } \\
\text { herbivorous } \\
\text { species }\end{array}$ \\
\hline Orthoptera: Acrididae & Chapco et al. 1997, 1999; Otte and Nasrecki 1997; Knowles and Otte 2000 & 23 \\
\hline Orthoptera: Acrididae: Melanoplus & & 7 \\
\hline Hemiptera & $\begin{array}{l}\text { Schuh 1976; Schuh and Slater 1995; Bourgoin et al. 1997; Henry 1997; } \\
\text { Dietrich 1999; J. R. Cryan, C. Bartlett, and M. F. Whiting, unpublished } \\
\text { manuscript }\end{array}$ & 38 \\
\hline Hemiptera: Cicadomorpha & & 14 \\
\hline Coleoptera & Lawrence and Newton 1982; Kukalová-Peck and Lawrence 1993 & 12 \\
\hline Diptera & $\begin{array}{l}\text { McAlpine et al. 1981, 1987; McAlpine 1989; Russo et al. 1995; Pitnick et } \\
\text { al. 1997; Yeates and Wiegmann } 1999\end{array}$ & 10 \\
\hline Diptera: Acalyptratae & & 9 \\
\hline Diptera: Drosophilidae: Drosophila & & 7 \\
\hline Lepidoptera & Kristensen and Skalski 1999; Lemaire and Minet 1999; Mitchell et al. 2000 & 29 \\
\hline Lepidoptera: Noctuoidea & & 14 \\
\hline
\end{tabular}

Note: To avoid repetition, references needed to build the tree for each ordinal group are listed under the coarsest taxon only. 


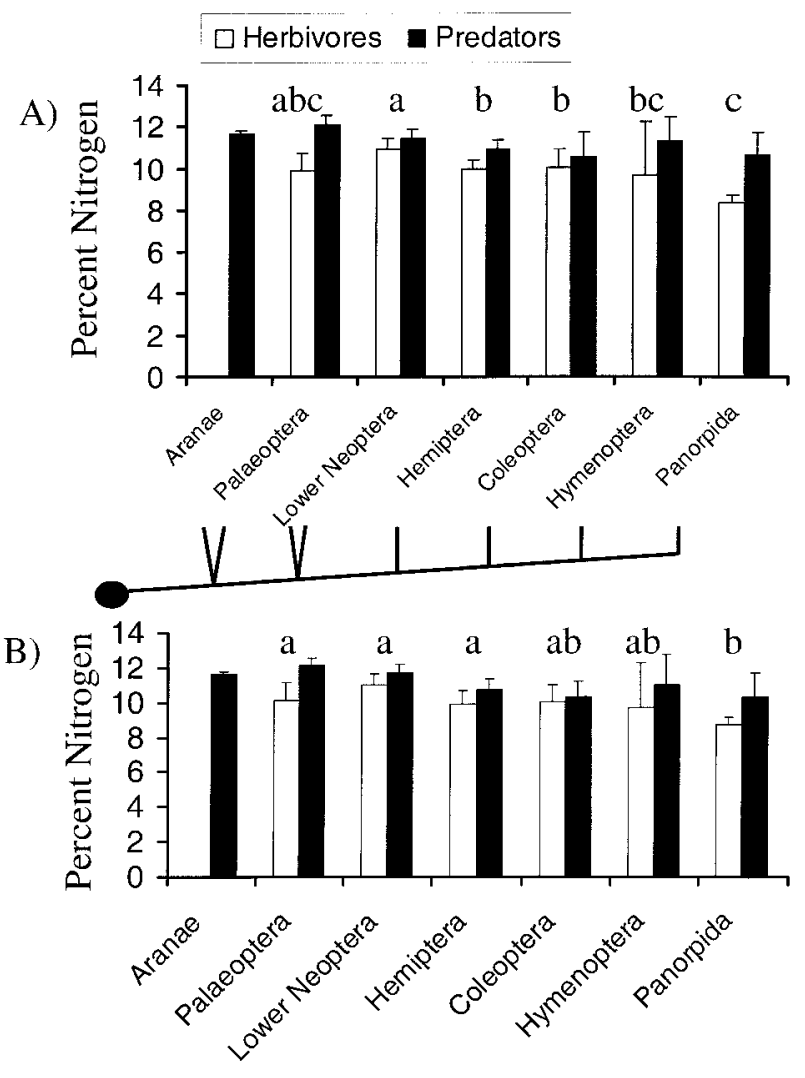

Figure 1: Mean $( \pm \mathrm{SE})$ nitrogen content across ordinal groupings of insects by trophic level. Nitrogen as a percentage of dry weight. $A$ uses all species in the database, whereas $B$ utilized within-family medians. The phylogenetic tree under $A$ gives a schematic overview of the interrelatedness of the different ordinal groupings. For each panel, herbivore groups not sharing letters above their bars were judged significantly different by ANCOVA. Data for spiders are presented for comparison only; they were not included in any statistical analyses.

imens and used two-way ANOVA with developmental stage (adult vs. immature) and ordinal group (available data restricted this to Orthoptera vs. Lepidoptera only) as factors to test for differences in $\mathrm{N}$ content. To maximize our sample size for this analysis, we assigned data points to immature or adult categories without regard to species identity. In a subsequent analysis, we used paired $t$-tests to identify potential differences within species across developmental stage for the one lepidopteran and three orthopteran species for which both adult and juvenile $\mathrm{N}$ measurements were available.

\section{Results}

\section{Predaceous Insects Have Higher Nitrogen Content than Herbivorous Insects}

This signal (fig. 1) persists after the effects of phylogenetic lineage and body size are accounted for in several ways and probably does not reflect dilution by gut contents (see data on gut contributions below). Across all species, herbivores averaged $9.65 \%( \pm 0.15 \mathrm{SE}) \mathrm{N}$ by mass, whereas predators averaged $11.03 \%( \pm 0.20) \mathrm{N}$, a $15 \%$ increase in proportional terms.

In the two-way ANCOVA, the main effect of trophic level was highly significant $(P<.001$; table 3$)$. Within ordinal groups, mean predator $\mathrm{N}$ content always exceeded the corresponding herbivore mean. Within-group mean differences ranged from $0.52 \%$ (Lower Neoptera) to $2.20 \%$ (Palaeoptera), with a mean within-order difference of $1.34 \%$. Eliminating the four species of omnivorous neoconocephaline grasshoppers increased the Lower Neopteran difference to $1.02 \%$. Herbivorous insects were also found to have significantly lower $\mathrm{N}$ content than predators in each of the alternative analyses involving sequential ANCOVAs, which first controlled for contributions of ordinal group and/or body length before testing for an effect of trophic level (table 3 ).

It was important to control for body length in these analyses because allometric changes in body $\mathrm{N}$ were a statistically significant source of variation in the data set (table 3). This was most true for predators, where we found a significant positive relationship between body $\mathrm{N}$ content and body length $\left(\% \mathrm{~N}=1.49 \times \log _{10}\right.$ body length +9.44 , $r^{2}=0.29, n=33, P=.001$; fig. 2). A similar regression for herbivores was nonsignificant with a shallower slope. The intercept for the herbivore regression was 9.20, nearly identical to that for predators. The slopes of the herbivore

Table 3: Dependence of insect percent nitrogen content on trophic level

\begin{tabular}{lccc}
\hline Type of analysis and variable & df & $F$ & $P$ \\
\hline Two-way ANCOVA: & & & \\
$\quad$ Trophic level & 1,139 & 13.849 & $<.001^{\star * *}$ \\
Ordinal group & 5,139 & 2.600 & $.027^{\star}$ \\
$\quad$ Ordinal group $\times$ trophic level & 5,139 & 1.714 & .135 \\
$\quad$ Body length & 1,139 & 3.854 & .052 \\
Sequential ANCOVA: & & & \\
$\quad$ Step 1: & 5,146 & 10.410 & $<.001^{\star * *}$ \\
$\quad$ Ordinal group & & & \\
Step 2: & 1,149 & 18.710 & $<.001^{\star * *}$ \\
$\quad$ Trophic level & 1,149 & 1.500 & .230 \\
$\quad$ Body length & & & \\
Sequential ANCOVA: & & & \\
$\quad$ Step 1: & 5,145 & 9.782 & $<.001^{\star * *}$ \\
$\quad$ Ordinal group & 1,145 & 2.545 & .112 \\
$\quad$ Body length & & & \\
$\quad$ Step 2: & 1,150 & 18.860 & $<.001^{\star * *}$ \\
$\quad$ Trophic level & &
\end{tabular}

Note: Analyses conducted on individual species' values. Percent nitrogen data subjected to angular transformation before analysis.

* Significant at $P<.05$.

$* * *$ Significant at $P<.001$. 


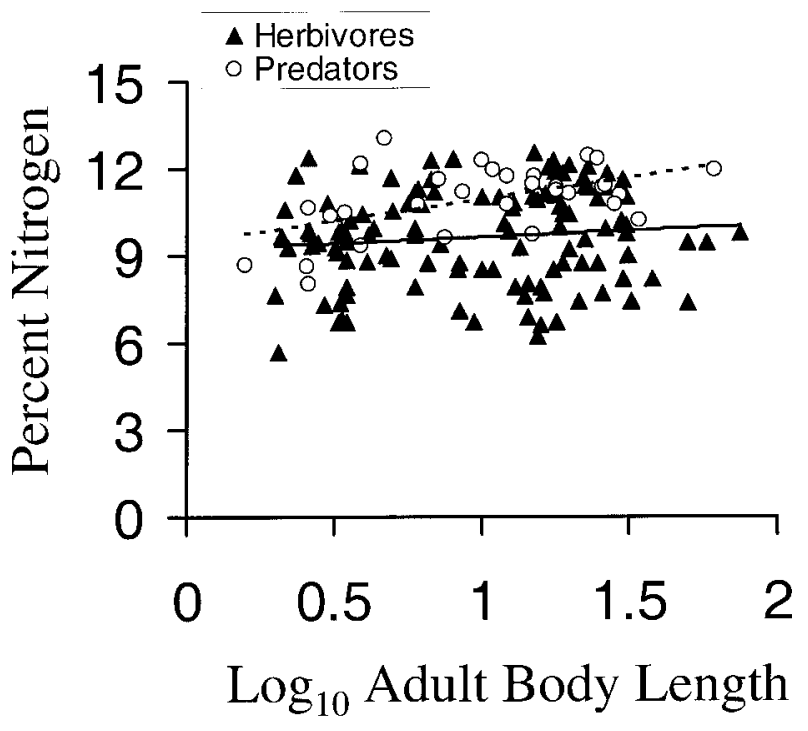

Figure 2: Regression of $\% \mathrm{~N}$ by species on body length for herbivores and predators.

and predator regressions were not significantly different from one another.

Mean $\mathrm{N}$ content of predaceous insects continued to exceed that of herbivores when we further controlled for phylogeny by using family-level medians (within ordinal groups) as the dependent variables (fig. 1B). Across all orders, both herbivore and predator mean $\mathrm{N}$ contents decreased slightly when using family-level data (to $9.54 \%$ [ $\pm 0.21 \mathrm{SE}]$ and $10.82 \%[ \pm 0.27]$, respectively). The difference across trophic levels, though somewhat smaller, remained significant in both factorial and sequential ANCOVAs (table 4). Within-ordinal group means of trophic-level differences ranged from $0.28 \%$ (Coleoptera) to $2.01 \%$ (Palaeoptera), with a mean within-group difference of $1.12 \%$.

An even more rigorous control for phylogeny, using a maximal number of independent contrasts regardless of taxonomic level, yielded similar results. Across these contrasts, we found no significant dependence of the difference in median $\mathrm{N}$ content between trophic levels on the corresponding difference in median body size (fig. 3). Across contrasts, the median $\% \mathrm{~N}$ of predator taxa consistently and significantly exceeded that of corresponding herbivore taxa (paired $t_{12}=2.46$, two-tailed $P=.030$, one-tailed $P=.015)$. On average, predators were $0.75 \%$ $( \pm 0.30 \mathrm{SE})$ richer in $\mathrm{N}$ than the corresponding herbivores, and in only two of 13 cases (both in beetles) did \% $\mathrm{N}$ of predators fail to exceed that of herbivores (see fig. 3). Substituting means for medians throughout this compar- ative analysis had no qualitative impact on either the regressions or the paired $t$-test results.

Other attempts to trim the compiled database also failed to eliminate the trophic signal. For example, eliminating nine freshwater insects and/or four orthopterans that were omnivorous rather than strictly predaceous had no qualitative effect on any of these tests, neither did using raw $\% \mathrm{~N}$ as the response variable instead of its angular transformation.

\section{For Herbivores, Nitrogen Content Varies among Major Insect Lineages}

Using species level data, we found that two different ANCOVAs (using first body length as a covariate and then both body length and a body length $x$ ordinal group interaction as covariates) revealed a significant difference in $\mathrm{N}$ content among ordinal groups of herbivorous insects $(P<.001$ for both; table 5$)$. These qualitative results did not depend on inclusion of the aquatic species. Plotting $\mathrm{N}$ content on the ordinal-level phylogeny (fig. 1A) suggests a phylogenetic trend toward decreasing $\% \mathrm{~N}$, particularly when only terrestrial taxa are considered. For example, the most recently originated orders Lepidoptera and Diptera (ordinal group Panorpida) exhibited significantly lower N content $(8.38 \% \mathrm{~N})$ than the older orders Coleoptera $(10.1 \%$ $\mathrm{N})$ and Hemiptera $(9.9 \% \mathrm{~N})$, while these in turn are sig-

Table 4: Dependence of insect percent nitrogen content on trophic level

\begin{tabular}{lccc}
\hline Type of analysis and variable & $\mathrm{df}$ & $F$ & $P$ \\
\hline Two-way ANCOVA: & & & \\
$\quad$ Trophic level & 1,52 & 6.567 & $.013^{*}$ \\
$\quad$ Ordinal group & 5,52 & 1.632 & .168 \\
$\quad$ Ordinal group $\times$ trophic level & 5,52 & 7.452 & .404 \\
$\quad$ Body length & 1,52 & 1.040 & $.009^{\star *}$ \\
Sequential ANCOVA: & & & \\
$\quad$ Step 1: & & & \\
$\quad$ Ordinal group & 5,59 & 3.275 & $.011^{\star}$ \\
$\quad$ Step 2: & 1,62 & 11.236 & $.001^{\star * *}$ \\
$\quad$ Trophic level & 1,62 & 4.124 & $.047^{\star}$ \\
$\quad$ Body length & & & \\
Sequential ANCOVA: & & & \\
$\quad$ Step 1: & 5,58 & 3.327 & $.010^{\star}$ \\
$\quad$ Ordinal group & 1,58 & 4.171 & $.046^{*}$ \\
$\quad$ Body length & & & \\
$\quad$ Step 2: & 1,63 & 12.157 & $<.001^{\star * *}$ \\
$\quad$ Trophic level &
\end{tabular}

Note: Analyses conducted on family-level medians. Percent nitrogen data were subjected to angular transformation before analysis.

* Significant at $P<.05$.

** Significant at $P<.01$

*** Significant at $P<.001$. 


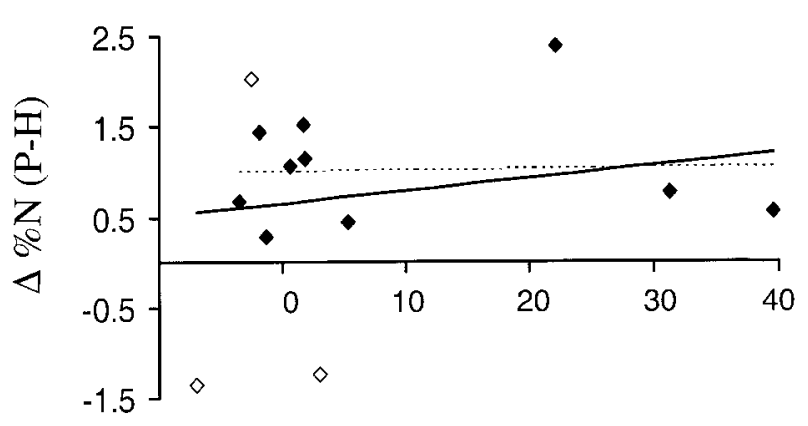

$\Delta$ Body Length (P-H)

Figure 3: Independence of difference between predator and herbivore nitrogen content $(\Delta \% \mathrm{~N}[\mathrm{P}-\mathrm{H}])$ and difference in body length ( $\Delta$ body length $[\mathrm{P}-\mathrm{H}]$ ) across 13 phylogenetically independent contrasts (identified in table 1). Solid line fitted to all data points. Dashed lined fitted to a reduced data set that omits contrasts within the Coleoptera (open diamonds).

nificantly less N-rich than the still older Lower Neoptera (10.94\% N; fig. 1A).

When family median was used as the response variable in the simpler ANCOVA (with body length as a covariate), the phylogenetic signal remained significant $(P=.034$; table 5), with the ordinal group means changing only slightly. Post hoc pairwise comparisons again highlighted the difference between Panorpida and more ancient lineages (fig. 1B). A sequential ANCOVA in which the first step gave precedence to effects of body length also indicated a significant effect of ordinal group within the residuals (table 5). A factorial ANCOVA in which the interactive effect body length $\times$ ordinal group appeared failed to indicate a significant effect of ordinal group; however, the interactive covariate did not provide a significant effect.

In contrast to the marked phylogenetic signal at the ordinal level and above, we found little evidence for phylogenetic conservatism of $\mathrm{N}$ content at lower taxonomic levels. The PTP tests for phylogenetic structure were carried out on herbivore $\% \mathrm{~N}$, with and without angular transformation, within 11 insect orders or subgroups thereof. Significant correlation with phylogeny was found only for the Acrididae $(P=.04)$, with essentially the entire signal resting on the low $\mathrm{N}$ values in the Cyrtacanthacridinae (three of which were species of Schistocerca) and the other three subfamilies represented in the database. The only other comparisons to approach significance were the PTP test on dipteran herbivores $(P=.11)$ and the two-sample permutation (Mann-Whitney) test of primitive versus advanced ditrysian lepidopterans $(.05<P$ [two-tailed] $<$ $.10)$. In contrast, the distribution of trophic level (herbivory vs. predation) was significantly correlated with phy-

logeny in Coleoptera $(P=.03)$ and Diptera $(P=.01)$ and nearly so in Hemiptera $(P=.06)$.

Restricting the database to records from adult terrestrial insects yielded results similar to those of the database as a whole (fig. $4 A, 4 B$ ). Specifically, we found that the effects of trophic level and ordinal grouping both remained significant when analyses were conducted at the species level, but when using family medians, the effect of trophic level was significant but the effect of ordinal grouping was not significant (table 6). Nitrogen content did not differ between adult and immature developmental stages within the two orders in which these were compared (fig. 4C). Two-way ANOVA found no significant effect of developmental stage on $\mathrm{N}$ content $(F=1.416$, df $=1,51$, $P=.240)$ and no interaction between developmental stage and order (Orthoptera vs. Lepidoptera; $F=0.003$, $\mathrm{df}=1,51, P=.954)$. Likewise, paired $t$-tests found no significant differences between the $\mathrm{N}$ content of adult and immature individuals of the same species $\left(t_{3}=2.740\right.$,

Table 5: Variation of percent nitrogen content of insect herbivores among ordinal groupings

\begin{tabular}{|c|c|c|c|}
\hline $\begin{array}{l}\text { Resolution of analysis, type of } \\
\text { analysis, and variable }\end{array}$ & $\mathrm{df}$ & $F$ & $P$ \\
\hline \multicolumn{4}{|l|}{ Species level: } \\
\hline \multicolumn{4}{|l|}{ ANCOVA: } \\
\hline Ordinal group & 5,112 & 10.880 & $<.001^{\star * *}$ \\
\hline Body length & 1,112 & .699 & .405 \\
\hline \multicolumn{4}{|l|}{ ANCOVA: } \\
\hline Ordinal group & 5,107 & 4.417 & $.001^{\star * \star}$ \\
\hline Body length & 1,107 & 4.228 & $.042^{\star}$ \\
\hline Ordinal group $\times$ body length & 5,107 & 4.210 & $.002^{\star *}$ \\
\hline \multicolumn{4}{|l|}{ Sequential ANCOVA: } \\
\hline \multicolumn{4}{|l|}{ Step 1: } \\
\hline Body length & 1,117 & 1.199 & .276 \\
\hline \multicolumn{4}{|l|}{ Step 2: } \\
\hline Ordinal group & 5,108 & 3.940 & $.003^{* *}$ \\
\hline \multicolumn{4}{|l|}{ Family-level medians: } \\
\hline \multicolumn{4}{|l|}{ ANCOVA: } \\
\hline Ordinal group & 5,36 & 2.745 & $.034^{\star}$ \\
\hline Body length & 1,36 & .953 & .333 \\
\hline \multicolumn{4}{|l|}{ ANCOVA: } \\
\hline Ordinal group & 5,31 & 1.503 & .217 \\
\hline Body length & 1,31 & 3.296 & .079 \\
\hline Ordinal group $\times$ body length & 5,31 & 2.333 & .066 \\
\hline \multicolumn{4}{|l|}{ Sequential ANCOVA: } \\
\hline \multicolumn{4}{|l|}{ Step 1: } \\
\hline Body length & 1,41 & .001 & .989 \\
\hline \multicolumn{4}{|l|}{ Step 2: } \\
\hline Ordinal group & 5,37 & 2.562 & $.044^{\star}$ \\
\hline
\end{tabular}

Note: Separate analyses conducted on species' values and family-level medians. Percent nitrogen subjected to angular transformation before analysis.

* Significant at $P<.05$.

$\star *$ Significant at $P<.01$.

$\star * *$ Significant at $P<.001$. 

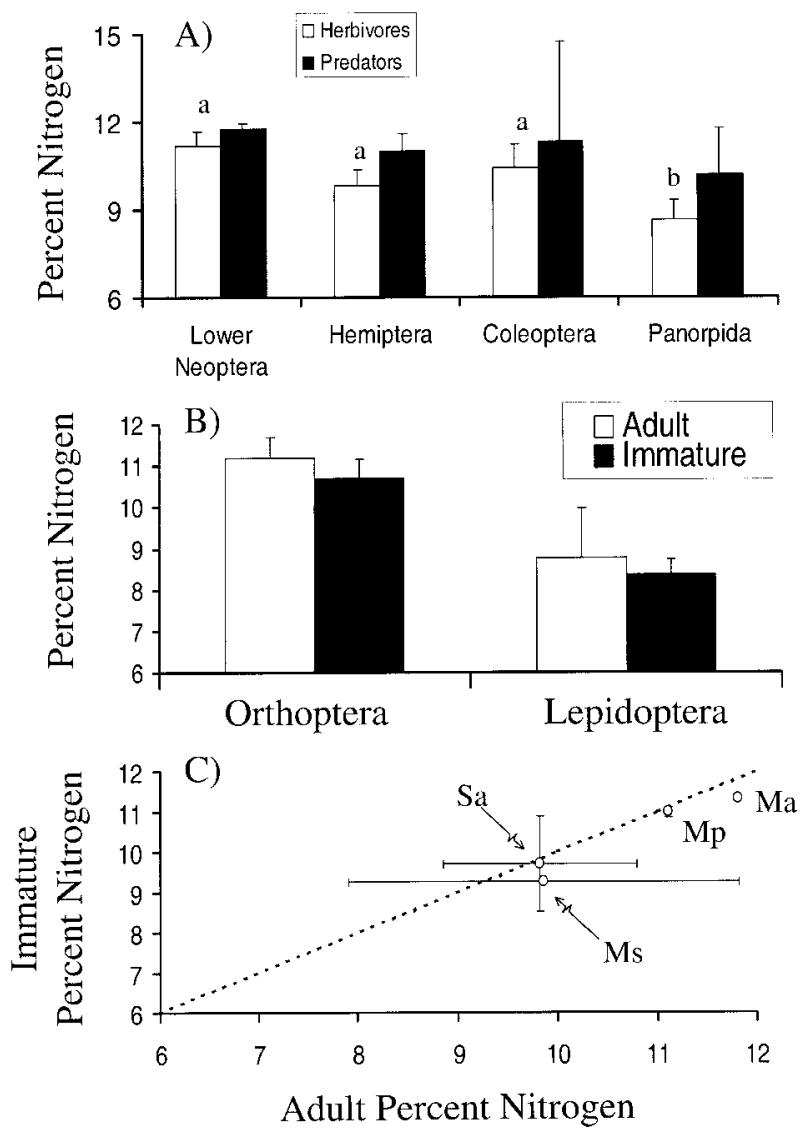

Figure 4: Influences of developmental stage on trophic and phylogenetic signals in insect nitrogen content. A presents results comparable to those in figure $1 A$ when only adult terrestrial insects were analyzed. Herbivore groups not sharing letters above their bars were judged significantly different by ANCOVA. $B$ and $C$ compare nitrogen content of immatures and adults within Orthoptera and Lepidoptera. $B$ assigns species to a developmental stage even if both stages are not represented in the database, whereas $C$ presents mean ( $\pm 95 \%$ confidence interval) using paired data for those species for which both immature and adult specimens are represented. Dotted line is a 1: 1 slope. Orthoptera: Sa (Schistocerca americana), Ma (Melanoplus angustipennis), Mp (Melanoplus packardii). Lepidoptera: Ms (Manduca sexta).

$P>$.07). However, immature specimens of each of the four species contained slightly less $\mathrm{N}$ than conspecific adults. On average, the intraspecific difference in $\mathrm{N}$ content between adult and immature stages was $0.33 \%( \pm 0.12 \mathrm{SE}$; fig. 4D). Overall, life stage differences appear unlikely to drive the emergent differences in $\mathrm{N}$ content among ordinal groups discussed above (fig. 1), such as the difference in $\mathrm{N}$ content between the Lower Neoptera and the Panorpida.

\section{Effects of Gut Dilution on Trophic Comparisons}

Total body $\mathrm{N}$ contents for dissected specimens of the orthopteran Orphulella pelidna and the lepidopteran Man- duca sexta were $11.83 \%$ ( $\pm 0.16 \mathrm{SE})$ and 9.27\% ( \pm 0.37$)$, respectively. Gut contents accounted for $14.5 \%( \pm 2.4)$ and $25.5 \%( \pm 1.3)$, respectively, of total dry mass and had $\mathrm{N}$ contents of $8.01 \%( \pm 0.95)$ and $4.02 \%( \pm 0.13)$. The value for $M$. sexta in this study (25.5\%) is consistent with values reported previously by Reynolds et al. (1985).

Can dilution by gut material account for the difference in total $\mathrm{N}$ content between predators and herbivores (average $1.38 \% \mathrm{~N})$ ? We evaluated this effect by calculating the percent $\mathrm{N}$ of the body excluding contributions from gut material. For predators, gut material is unlikely to affect total $\mathrm{N}$ content strongly, both because the material consists largely of other insects ( $\mathrm{N}$ content between $9.5 \%$ and $11 \%$ ) and because it is likely to comprise a small fraction (<10\%) of total dry mass (e.g., Cain et al. 1995). Thus, a conservative assumption is that the $\mathrm{N}$ content of predator carcasses (excluding gut content) is the same as average total body $\mathrm{N}$ content $(11.07 \%)$. For herbivores, additional calculations are possible using the data on gut material reported above. An average herbivore (total body $\mathrm{N}$ of $9.65 \%$ ) with gut material like that in Orphulella would have a carcass $\mathrm{N}$ content (excluding gut material) of $9.94 \%$ (i.e., carcass $\% \mathrm{~N}=[9.65-0.15 \times 8] / 0.85)$. And an average herbivore with gut material like that in Manduca would have a carcass $\mathrm{N}$ content of $11.53 \%$.

Thus, whether dilution by gut material accounts for the difference in $\mathrm{N}$ content between trophic levels depends on

Table 6: Tests for effects of trophic level and ordinal grouping when only adult terrestrial insects are considered

\begin{tabular}{|c|c|c|c|}
\hline $\begin{array}{l}\text { Resolution of analysis, type of } \\
\text { analysis, and variable }\end{array}$ & df & $F$ & $P$ \\
\hline \multicolumn{4}{|l|}{ Species level: } \\
\hline \multicolumn{4}{|l|}{ Two-way ANCOVA: } \\
\hline Trophic level & 1,73 & 5.402 & $.023^{\star}$ \\
\hline Ordinal group & 3,73 & 2.175 & .098 \\
\hline Ordinal group $\times$ trophic level & 3,73 & 1.963 & .165 \\
\hline Body length & 1,73 & 1.040 & .773 \\
\hline \multicolumn{4}{|l|}{ ANCOVA on herbivores only: } \\
\hline Ordinal group & 3,63 & 4.683 & $.005^{\star *}$ \\
\hline Body length & 1,63 & 1.123 & .293 \\
\hline \multicolumn{4}{|l|}{ Family-level medians: } \\
\hline \multicolumn{4}{|l|}{ Two-way ANCOVA: } \\
\hline Trophic level & 1,26 & 3.729 & .064 \\
\hline Ordinal group & 3,26 & 1.497 & .239 \\
\hline Ordinal group $\times$ trophic level & 3,26 & 2.655 & .103 \\
\hline Body length & 1,26 & .223 & .879 \\
\hline \multicolumn{4}{|l|}{ ANCOVA on herbivores only: } \\
\hline Ordinal group & 3,19 & 2.287 & .111 \\
\hline Body length & 1,19 & 1.118 & .304 \\
\hline
\end{tabular}

Note: Percent nitrogen subjected to angular transformation before analysis.

* Significant at $P<.05$.

** Significant at $P<.01$. 
the nature of the gut material. That is, gut material like that in Orphulella accounts for only $20 \%$ of the $1.38 \%$ difference between trophic levels, whereas gut material like that in Manduca more than accounts for the difference between trophic levels. Unfortunately few published data are available for evaluating whether the average herbivorous insect has gut contents more like those of Ophulella or Manduca. Gut material comprised $14.7 \%$ of dry mass in nymphs of three species of Plecoptera (two omnivores and one detritivore; Cain et al. 1995) and about $10 \%$ of dry mass in larvae of the herbivorous lepidopteran Hemileuca lucina (Saturniidae; Bowers et al. 1991). These data suggest that other herbivorous insects have gut contents more like those of Orphulella than Manduca. However, additional work evaluating this factor clearly would be desirable.

\section{Discussion}

Our analyses revealed a striking divergence in $\mathrm{N}$ content between insect herbivores and predators. We also found significant differences in $\mathrm{N}$ content among the major lineages of herbivores in the data set, with recently derived groups, most notably the Panorpida (a monophyletic group that includes the Diptera and Lepidoptera from our data set plus other taxa not represented), having lower $\mathrm{N}$ content than more ancient groups such as the orders Orthoptera and Hemiptera. In what follows, we outline a series of hypotheses concerning the origin and implications of the persistent difference in body elemental composition between predaceous and herbivorous insects. Subsequently, we discuss the phylogenetic signal in depth, outlining possible connections between changes in body nitrogen content and the evolutionary diversification of insects.

Why do predaceous and herbivorous insects differ in body $\mathrm{N}$ content? We have identified explanations that fall into five broad categories. First, the difference may reflect allometric effects, phylogenetic influences, or other, unrecognized biases within the database. Second, differential body composition may reflect the net developmental outcome of differential nutrient availability from herbivory versus predation. In other words, predators may have higher body $\mathrm{N}$ than herbivores simply as a consequence of eating higher$\mathrm{N}$ food than herbivores. Third, differential body composition may be selected for directly (in herbivores, predators, or both) in response to the differential scarcity of dietary $\mathrm{N}$. For example, herbivores might be able to adapt to low$\mathrm{N}$ food by substituting low- $\mathrm{N}$ materials for high- $\mathrm{N}$ materials in constructing some body parts. Fourth, differential $\mathrm{N}$ content may be an indirect consequence of adaptation to different trophic habits. For example, herbivory and predation might select for different allocations to muscle versus other, lower- $\mathrm{N}$ structures. The third and fourth classes of explanations need not be mutually exclusive. The fifth expla- nation, in contrast, is distinct. Under this scenario, higher $\mathrm{N}$ in predators may reflect sequestration or other adaptive (or maladaptive) responses to problems created by a dietary $\mathrm{N}$ supply that exceeds their needs. We discuss these five possibilities in turn.

\section{Methodological Issues and Potential Artifacts}

Data compiled for macroecological studies present different analytical challenges from those obtained through controlled experiments (Blackburn and Gaston 1998). As we tested for trophic and phylogenetic signals in the data set, we sought to quantify and account for as many extraneous sources of variability as possible. One potential artifact arises from the haphazard taxonomic distribution of currently available $\% \mathrm{~N}$ values. Strong phylogenetic constraints on $\mathrm{N}$ content at lower taxonomic levels would invalidate analyses that offer the greatest potential statistical power because they treat species- or family-level data within trophic levels and within broader lineages as independent. Our permutation tests, however, showed that phylogenetic conservation of $\mathrm{N}$ content within and among related families is weak to nonexistent, supporting the use of those more powerful analyses. The emergence of $\mathrm{N}$ content as an evolutionarily labile trait does not itself seem to be an artifact of sparse representation of species. Indeed, the same data set strongly supports the nonrandom phylogenetic distribution of predation versus herbivory. In future studies, it will nonetheless be desirable to control for phylogeny, particularly as phylogenetic signals are clearly evident at the broadest scale. In addition, obtaining $\% \mathrm{~N}$ in a taxonomically deliberate fashion would greatly increase the efficiency of the statistical design. For example, the number of independent contrasts available for testing the difference between trophic levels could be increased from 13 to 20 with the addition of just seven species (e.g., predaceous or parasitic members of the largely herbivorous Lepidoptera, herbivorous members of the largely predatory Coccinellidae).

Observer bias caused by differences in analytical methods for different sets of data is unlikely to be responsible for the observed trends. First, it is general practice in analysis of $\mathrm{N}$ content in biological materials to include internal standards from either the National Institute of Standards and Technology (NIST) or commercial suppliers having rigorous internal calibrations. Thus, analytical procedures can easily diagnose over- or underestimates of sample $\mathrm{N}$ content. Second, few methods for $\mathrm{N}$ analysis of biological materials exist. Essentially, there are two: the most widely used method, the dry Dumas combustion method, and a method involving wet digestion of material followed by colorimetric analysis (Kjeldahl method). These methods have been extensively cross-correlated and show excellent 
correspondence (Perez et al. 2001; Watson and Galliher 2001).

\section{Changes in Body Nitrogen Composition of Individuals as a Consequence of Diet}

Dietary $\mathrm{N}$ availability may directly influence body $\mathrm{N}$ content of individual insects. We see two related mechanisms by which such an effect could occur. First, insects eating $\mathrm{N}$-poor foods may have low total $\mathrm{N}$ content as a result of dilution by low-N gut material. Differential dilution by gut contents as a function of body size may also contribute to the different allometric responses between herbivores and predators (fig. 2). Overall, our laboratory analyses of two species suggest that gut dilution may contribute to, or potentially even explain, the differences observed between herbivores and predators and among herbivore lineages. However, the trophic and phylogenetic signals largely persisted when we restricted our analyses to adult insects only (fig. 4; table 6), which should have reduced any contribution that the potential for disproportionately large gut volumes among larval holometabolous insects may have made to the initial patterns we observed (see Dow 1986 for an overview of comparative insect gut structure and function). Nevertheless, given the small sample sizes involved in the laboratory analyses and the adults-only database, the issue needs to be clarified by additional work on other species. Future efforts could also standardize effects of gut-dilution across species by using only specimens with voided or excised guts.

In one sense, this gut-dilution hypothesis could be viewed as a kind of methodological artifact. However, when insects are viewed from a functional perspective (i.e., as nutrient recyclers or food for other consumers), it is the entire nutrient packet that matters, and this may weaken the need to distinguish between gut material and body tissues. Our database suggests that, on a per unit mass basis, whole animal nitrogen content may vary as much as 2.3 -fold among insect species, with differences among individuals approaching threefold. Thus, a bird feeding on high-N insects, like dragonflies or coccinellid beetles, may enjoy a substantially enhanced rate of nutrient intake compared with a bird gleaning caterpillars with large amounts of leaves in their guts. Likewise, as a result of the variation in the nutrient content of the packet, dead insects from different species may diverge considerably in the degree to which they represent a local resource pool for decomposers. In contrast, other functional issues require that the distinction between gut contents and body tissues be maintained. For example, stoichiometric principles (Sterner and Elser 2002) dictate that interspecific differences in the $\mathrm{N}$ content of herbivore body tissues would translate into differential withdrawals of nitrogen from the plant trophic level to form the insect bodies. Put simply, interspecific differences not attributable to gut dilution would mean that it takes less nitrogen to build a kilogram of, say, noctuid moth tissue than it does to build a kilogram of acridid grasshopper tissue. Thus, not just the abundance but also the biochemical makeup of the insect herbivores in a community would have the potential to influence nutrient turnover rates.

Second, and regardless of the diluting effects of gut material, individuals eating low- $\mathrm{N}$ foods may have lower $\mathrm{N}$ content in all body tissues than conspecifics with access only to high-N foods. If so, higher tissue $\mathrm{N}$ content in predators may directly reflect higher dietary $\mathrm{N}$ availability rather than evolutionary shifts in body composition (see below). Evaluating this possibility boils down to examining the degree of intraspecific or intraindividual homeostasis in tissue $\mathrm{N}$ content, as discussed earlier. Whether plasticity in body $\mathrm{N}$ content accounts for the systematic difference between predators and herbivores could be addressed experimentally by comparing individuals from omnivorous species forced to be exclusively predaceous or herbivorous.

\section{Evolutionary Shifts in Body Nitrogen Composition in Response to Diet}

An intuitively appealing explanation for the lower $\mathrm{N}$ content of herbivore bodies is that, as an adaptation to chronic fitness limitation by dietary $\mathrm{N}$, herbivorous insects have evolved a lower dependence on $\mathrm{N}$ for the construction of one or more body constituents. A complementary hypothesis is that predators might have evolved to make greater structural use of $\mathrm{N}$ because it is in relatively greater supply in their diets. Such shifts may also contribute to the potential differential dependence of $\% \mathrm{~N}$ on body length for predators and herbivores (fig. 2). A definitive test of such hypotheses will require detailed dissection and comparison of the distribution of $\mathrm{N}$ content across the biochemical pools and anatomical structures of herbivorous and predaceous insects. Where such evolved differences might lie is at present entirely unexplored, but several levels at which evolution could modify $\mathrm{N}$ content are conceivable. At the level of building-block monomers, selection could potentially act on the variation in $\mathrm{N}$ content within structural classes of amino acids and perhaps even nucleotides (especially rRNA). Indeed, recent work on the elemental composition of proteins from Escherichia coli and Saccharomyces cerevisiae suggests that protein composition can evolve in response to shortages of particular elements (Baudouin-Cornu et al. 2001). At the tissue level, trade-offs may be possible between macromolecules that contain more or less N. For example, selection might modify the ratio of protein (typically $\sim 17 \% \mathrm{~N})$ to chitin $(2.3 \%$ N) in insect cuticle, which typically ranges from $4: 1$ to 
$1: 1$ (Chapman 1982). At the level of the entire body plan, selection might modify the relative allocations to muscle, cuticle, fat body, and other tissues, all of differing $\mathrm{N}$ content.

Particularly at higher levels of organization, it may be difficult to distinguish between the effects of selection directly on nitrogen content and indirect effects resulting from selection on functional morphology. For example, predators may allocate more resources to muscle than do herbivores as a means of capturing or overpowering their prey. Increased allocation to muscle would tend to increase total body $\mathrm{N}$ content. In this instance, selection on elemental composition per se and selection on function are mutually reinforcing. In other instances, these selective forces could conflict. For example, selection for lower N requirement in herbivores could favor less allocation to muscle and exoskeleton but be opposed by selection for greater allocation to the chewing muscles necessary to process tough plant materials.

Although the specific pathways by which selection might result in a trophic difference in $\mathrm{N}$ content are still unexplored, substantial evidence does exist concerning one prediction of the adaptation-to-N-shortage hypothesis. Nitrogen limitation on herbivore fitness is sufficiently pervasive (e.g., McNeill and Southwood 1978; Mattson 1980; Strong et al. 1984; White 1993; Cook and Denno 1994; Dixon 1998) to suggest a strong potential selective advantage to changes in body composition that would lower dietary $\mathrm{N}$ requirements.

\section{Excess Nitrogen for Predators?}

A final class of explanations for the differences in $\mathrm{N}$ content between trophic levels invokes the possibility that arthropod predators may take in more $\mathrm{N}$ than they need. Nitrogenous wastes are generally toxic, and animal species have evolved numerous ways of excreting, sequestering, or otherwise ridding themselves of unneeded $\mathrm{N}$.

On the surface at least, several lines of evidence suggest that predatory arthropods might face and be stressed by an excess of $\mathrm{N}$ in their diets. For example, Schizocosa wolf spiders exhibit higher survival and growth rates when feeding on collembolans than when feeding on conspecifics, which would be expected to afford predators the optimal dietary stoichiometry (Toft and Wise 1999b). However, collembolans, for which we could find no body $\% \mathrm{~N}$ data, may in fact be very rich in $\mathrm{N}$ because they tend to accumulate rather than excrete $\mathrm{N}$ during their lifetimes (Chapman 1982; Hopkin 1997). Similar examples involve predaceous mites (MacRae and Croft 1997) and Coccinella ladybird beetles (Yasuda and Ohnuma 1999). However, all of these examples may confound stoichiometry with other factors affecting prey suitability, such as differences in ease of capture and in handling time (Riechert and Harp 1986; Endo and Endo 1994). Another observation that might suggest an excess of $\mathrm{N}$ is the high concentration of guanine, a principal nitrogenous excretory product, in the exoskeletal pigments of spiders (Oxford 1998). However, coloration in spiders has many functions, including crypsis, aposematism, and thermoregulation, and maintaining stored guanine costs more than evacuating it (Oxford 1998). Thus, this nitrogenous "waste" may in fact be retained for adaptive reasons and should not necessarily be viewed as excess (see also Timmermann and Berenbaum 1999).

\section{Nitrogen Limitation of Insect Predators and Its Consequences for Food-Web Complexity}

In contrast to the weak support for a harmful excess of $\mathrm{N}$, several lines of evidence strongly suggest that dietary $\mathrm{N}$ limits predatory arthropods as it does herbivores. For example, reclamation of silk by web-spinning spiders (Peakall 1971; Opell 1998) and cuticle feeding in centipedes (Lewis 1981) appear to be behavioral/physiological mechanisms for $\mathrm{N}$ and protein conservation. Likewise, some invertebrate predator species prefer to feed on $\mathrm{N}$ rich prey (Hagen 1986), and others, when supplementing their carnivorous diets with plant material, specifically seek out the protein-rich pollen (Hagen 1986). Many parasitoid wasps obtain supplemental $\mathrm{N}$ through host feeding, in which adult wasps feed on rather than oviposit in potential hosts to secure protein for egg development (Jervis and Kidd 1986; Chan and Godfray 1993; Heimpel et al. 1997; Thompson 1999).

Preferences for N-rich prey may promote predation on other predators, leading to increased intraguild predation (Hodge 1999). Examples of such dietary preferences include hunting spiders (Nyffeler 1999; Finke and Denno 2002) and some heteropterans (Rosenheim et al. 1993). In several cases, intraguild predation has been shown to increase components of predator fitness (Jackson and Kester 1996; Li and Jackson 1997). Substantial evidence indicates that, as for herbivores, experimental increases in dietary $\mathrm{N}$ availability can lead to increased growth, survival, and/or reproduction in predatory arthropods (tachinid flies: Bonnot 1986; spiders: Furrer and Ward 1995; Toft 1999). Data also suggest, however, that $\mathrm{N}$ must be available in the appropriate form (e.g., not accompanied by prey toxins) for predators to benefit (Toft and Wise $1999 a, 1999 b)$. This argument has been used to explain the improved performance of spiders on mixed- compared with single-species diets (Riechert and Harp 1986; Uetz et al. 1992).

The consistent disparity in $\mathrm{N}$ contents of herbivorous and predatory insects (figs. 1,3) raises the question of 
whether the increased $\mathrm{N}$ demands for body growth of predators exposes them to the risk of $\mathrm{N}$ limitation for their growth. Stoichiometric theory permits an estimation of this possibility. By using information about a predator's $\mathrm{N}$ requirements and its efficiency in retaining carbon $(\mathrm{C})$ and N from ingested food (Urabe and Watanabe 1992), one can estimate the threshold elemental ratio (TER), the prey $\mathrm{C}: \mathrm{N}$ ratio above which the predator should experience a growth penalty. Expressed in terms of $\mathrm{C}: \mathrm{N}$ ratios, the TER in a predator-prey interaction is given by

$$
\mathrm{TER}_{\mathrm{C}: \mathrm{N}}=\frac{\alpha_{\mathrm{N}}^{\prime}}{\alpha_{\mathrm{C}}^{\prime}} \mathrm{C}: \mathrm{N}_{\text {predator }},
$$

where $\alpha_{\mathrm{N}}^{\prime}$ is the maximum gross growth efficiency for $\mathrm{N}$ (i.e., the fraction of ingested $\mathrm{N}$ that the animal converts into new biomass), $\alpha_{\mathrm{C}}^{\prime}$ is the maximum gross growth efficiency for $\mathrm{C}$ (as for $\mathrm{N}$ ), and $\mathrm{C}: \mathrm{N}_{\text {predator }}$ is the $\mathrm{C}: \mathrm{N}$ ratio of predator biomass that is assumed to be specific to the predator in question and under strong homeostatic regulation. For a given set of values of $\mathrm{C}: \mathrm{N}_{\text {predator }}, \alpha_{\mathrm{C}}^{\prime}$, and $\alpha_{\mathrm{N}}^{\prime}$, when prey $\mathrm{C}: \mathrm{N}$ exceeds $\mathrm{TER}_{\mathrm{C}: \mathrm{N}}$, then the predator is experiencing a limitation by the $\mathrm{N}$ content of its food and must reduce its gross growth efficiency for $\mathrm{C}$ in order to maintain homeostasis in body $\mathrm{C}: \mathrm{N}$. This formulation allows us to ask the following question: given an observed imbalance in $\mathrm{C}: \mathrm{N}$ between a predator and a prey item, what combination of $\alpha_{\mathrm{N}}^{\prime}$ and $\alpha_{\mathrm{C}}^{\prime}$ values would imply $\mathrm{N}$-limited predator growth? Rearranging the above formula, $\mathrm{N}$-limited predator growth would occur when

$$
\frac{\mathrm{C}: \mathrm{N}_{\text {prey }}}{\mathrm{C}: \mathrm{N}_{\text {predator }}}>\frac{\alpha_{\mathrm{N}}^{\prime}}{\alpha_{\mathrm{C}}^{\prime}} .
$$

To evaluate this possibility with our data, we converted observed data for $\% \mathrm{~N}$ to a corresponding $\mathrm{C}: \mathrm{N}$ ratio, assuming a mean value of $46 \%$ for herbivores and $49 \%$ for predators, giving mean $\mathrm{C}: \mathrm{N}$ ratios of 5.8 and 5.1 , respectively. What values of $\alpha_{\mathrm{C}}^{\prime}$ and $\alpha_{\mathrm{N}}^{\prime}$ would imply $\mathrm{N}$ limitation of the predator given this modest $\mathrm{C}: \mathrm{N}$ imbalance? If we use an upper value for the efficiency of extracting $\mathrm{N}$ from the diet of $\sim 70 \%\left(\alpha_{\mathrm{N}}^{\prime}=0.70\right)$, then a predator experiencing this degree of imbalance (5.8 vs. $5.1 \mathrm{C}: \mathrm{N}$ ) could accomplish a $\mathrm{C}$ growth efficiency of $\sim 0.65$ before encountering $\mathrm{N}$ limitation. An $\alpha_{\mathrm{C}}^{\prime}$ value of 0.65 is quite high and likely only for animals encountering high densities of prey such that basal metabolic costs and the respiratory costs of movement are relatively small proportions of the overall $\mathrm{C}$ balance. Note, however, that this assessment compares the mean predator and prey $\mathrm{C}: \mathrm{N}$ values; particular predator-prey combinations may involve more severe $\mathrm{C}: \mathrm{N}$ imbalance, making $\mathrm{N}$ limitation of the predator more likely. For example, in our data set, her- bivorous aphids have a very low $\mathrm{N}$ content $(\mathrm{C}: \mathrm{N} \sim 9.6)$, whereas the aphid-specialist predator Hippodamia parenthesis has a high $\mathrm{N}$ content $(\mathrm{C}: \mathrm{N} \sim 4.4)$. For this predatorprey combination, predator growth with $\alpha_{\mathrm{C}}^{\prime}$ of 0.65 would be $\mathrm{N}$ limited no matter how efficient the predator was at extracting N. Assuming $\alpha_{\mathrm{N}}^{\prime}=0.7$, this predator would only be able to grow with $\alpha_{\mathrm{C}}^{\prime} \leq 0.33$ without experiencing N limitation. Southwood (1973) reported that the energetic efficiency of predators (comparable to $\alpha_{\mathrm{C}}^{\prime}$ ) ranged from 0.38 to 0.51 . Clearly, our calculations are approximate, and detailed data on $\mathrm{C}$ and $\mathrm{N}$ metabolism on particular prey-predator pairs are needed to characterize these thresholds more precisely. Nevertheless, these calculations suggest that stoichiometric growth limitation by $\mathrm{N}$ is a real possibility for predaceous insects. Thus, $\mathrm{N}$-limited consumer growth, already well documented at the herbivore level (White 1993), may extend to the third trophic level in some terrestrial food webs.

A broad ecological implication of the foregoing discussion is that $\mathrm{N}$ limitation of predatory insects (and perhaps terrestrial arthropod predators in general) may contribute to the stability and complexity of terrestrial arthropod food webs by favoring predation on other predators (see Fagan 1997; McCann and Hastings 1997). It has long been recognized that terrestrial arthropod food webs exhibit a high frequency of broadly generalized predators, extensive predation across multiple trophic levels, and high connectance (e.g., Polis 1991; Denno et al. 2002). Further evidence that $\mathrm{N}$ limitation contributes to intraguild predation and trophic complexity in terrestrial food webs could come from additional data showing higher $\mathrm{N}$ in predators that specialize in feeding on other predators such as obligate hyperparasitoids or lynx spiders (Oxyopidae). A suggestive example in our data set is the spider-feeding pompilid wasp, whose $12.5 \% \mathrm{~N}$ content is one of the highest among the 152 species we surveyed. Such data would also indicate whether enrichment of $\mathrm{N}$ content across trophic levels continues upward through the food web beyond herbivore-predator linkages. This line of reasoning is developed in more detail elsewhere (Denno and Fagan 2003).

\section{Nitrogen Content Variation among Major Herbivore Lineages}

Correlation of $\mathrm{N}$ content with phylogeny is most strongly evident at the ordinal group level. This variation gives the appearance of a phylogenetic trend toward decreased \%N in successively more recent groups (fig. 1), particularly if only the terrestrial groups are considered. The alternative, depending on how $\% \mathrm{~N}$ is expressed, would be that only Panorpida, or only Panorpida and lower Neoptera, are different from the rest. The trend hypothesis cannot be ruled out, but our database does not include enough of 
the branch points on the ordinal phylogeny to provide a rigorous test of the kind proposed, for example, by Sidor (2001).

In contrast with the signal at the ordinal group level, $\mathrm{N}$ content shows relatively little correlation with phylogeny at lower taxonomic levels, leading to the conclusion that the biological characteristics influencing $\mathrm{N}$ content may evolve relatively rapidly. This conclusion does need qualification, however. First, the apparent degree of variation at lower taxonomic levels includes any nongenetic sources of variation and would presumably be lower if experimental methodology had been standardized, as discussed earlier. Second, the rarity of significant phylogenetic signals as judged from our PTP analyses is likely due, in part, to the fact that our database represents a sparse and haphazard sampling of the millions of extant species of insects. For example, there are relatively few multiply represented genera in our database, but a number of congeneric pairs have strikingly similar values. It does seem clear, however, that $\mathrm{N}$ content is much less conserved than trophic level, for which the phylogenetic signal is strong in our database.

Variation in $\% \mathrm{~N}$ among herbivore lineages, like that between trophic levels, could arise from several causes. For example, it could result from current natural selection, representing a direct adaptation of body composition to differences in dietary N. Alternatively, the signal could represent a secondary effect of evolution in other traits, such as the potential need for greater commitment to muscle (a high- $\mathrm{N}$ body constituent) in herbivores feeding on relatively tough plant material (Bernays 1986).

Yet another class of explanations would ascribe amonglineage variation in $\% \mathrm{~N}$ to the retention of adaptations to previous, rather than current, selective regimes, a process sometimes referred to as phylogenetic constraint or inertia. Several such historical influences on $\% \mathrm{~N}$ can be imagined.

Time since Adoption of Phytophagy. Full adjustment of body $\mathrm{N}$ content to a change in trophic habits might entail many independent genetic changes and require considerable evolutionary time. If so, we might expect extant representatives of lineages that have only recently adopted phytophagy to show higher $\mathrm{N}$ requirements than species with a longer history of phytophagy, if both evolved phytophagy from the same antecedent habit. A variant of this hypothesis is that, if $\mathrm{N}$ efficiency facilitates herbivore success, the more recently differentiated members of a phytophagous clade might be expected to have lower $\mathrm{N}$ than those arising earlier. Our analysis of the Lepidoptera, in which the $\mathrm{N}$ content of the advanced clade Macrolepidoptera is marginally lower than more primitive lineages $(P<.05$ for a one-tailed test only), might reflect such a trend, but much broader sampling of basal lepidopterans is needed.
Antecedent Habit to Phytophagy. If evolution of body nutrient content occurs slowly, then assuming equal time for evolutionary change, we might expect higher $\mathrm{N}$ content in lineages that evolved plant-feeding from ancestral use of high- $\mathrm{N}$ foods. For example, herbivore lineages descended from predators should have higher $\mathrm{N}$ content than those descended from detritivores.

Ambient N Stress at Time of Origin. Plant nutrient content varies strongly with ambient light, temperature, and $\mathrm{CO}_{2}$ availability (Greenwood 1976; Peñuelas and Matamala 1990; Yin 1993; Marschner 1995; Bezemer and Jones 1998; Curtis and Wang 1998), all of which have fluctuated markedly over geological time (Berner 1994, 1998; Cerling et al. 1998). Sufficient evolutionary inertia could result in phytophagous clades that originated during $\mathrm{N}$-stress episodes showing lower $\mathrm{N}$ requirements than those that originated at other times.

Some anecdotal evidence suggests that past episodes of $\mathrm{N}$ stress have led to the evolution of novel insect structures and/or feeding strategies possibly related to nutrient availability. For example, major elevations of atmospheric $\mathrm{pCO}_{2}$, lasting a few tens of millions of years and reaching $\mathrm{CO}_{2}$ concentrations 10 -fold higher than those just before the Industrial Revolution (2,000-3,000 vs. $280 \mathrm{ppmv})$, occurred during the Permian (275-325 million years ago) and again in the Jurassic (150-225 million years ago; Berner 1994; Ekart et al. 1999). Given that plant $C: N$ ratios have increased in response to the relatively modest increases in $\mathrm{CO}_{2}$ levels in historic times (Peñuelas and Matamala 1990), it seems plausible that these substantially larger ancient increases in atmospheric $\mathrm{CO}_{2}$ may also have influenced plant nutritional chemistry and accentuated $\mathrm{N}$ shortage for herbivores (and possibly other trophic levels). Perhaps not coincidentally, each of these paleoatmospheric $\mathrm{CO}_{2}$ spikes coincides with the origin of several major phytophagous insect clades (Labandeira and Sepkoski 1993; Labandeira et al. 1994; Burmester et al. 1998). Similarly, pollen feeding, which can provide a major nutritional supplement to N-poor diets, seems to have two major origins, once in the early Permian and then again during the Jurassic (Krassilov and Rasnitsyn 1997; Labandeira 1997, 1998). Cerling et al. (1998) have linked the late-Miocene global expansion of $\mathrm{C}_{4}$ plants (which are generally $\mathrm{N}$ poor because of their reduced requirements for $\mathrm{N}$-rich Rubisco; Marschner 1995) to the evolution of mammalian grazers, and insects might have been affected as well. Although our current database is insufficient for such analyses, in the future it will be desirable to test both current-adaptation and historical hypotheses simultaneously via an expanded factorial analysis like the one already employed in this study. 


\section{Implications for Insect Diversification}

Hypotheses invoking phylogenetic constraint or inertia to account for variation in $\mathrm{N}$ content carry a further implication concerning the possible influence of $\mathrm{N}$ requirements on the relative diversification rate of insect herbivore lineages. If $\mathrm{N}$ limitation is ubiquitous and severe and only rarely or slowly ameliorated by adaptation, then herbivore lineages that do acquire such adaptations may enjoy an increase in mean individual fitness translating into an increased rate of speciation, lowered rate of extinction, or both. Thus, differential diversification among herbivore lineages could result, in part, from their differential ability to thrive on low-N diets. It is also possible that adoption of herbivory presents fewer barriers and will occur more readily from antecedent habits that preadapt insects to the low $\mathrm{N}$ content of plants. The fact that phytophagy has originated primarily from detritivorous rather than carnivorous ancestry (Mitter et al. 1988) might reflect the difficulty of switching from a high- to a low-N food source. Postulates of this kind deserve test. While the differential success of herbivore lineages has been more often ascribed to their ability to overcome plant defenses including secondary chemistry (e.g., Ehrlich and Raven 1964; Farrell et al. 2001), our results suggest that it may be time to reexamine the influence of basic nutrients on major features of insect evolution.

\section{Acknowledgments}

This article represents a contribution from the ecological stoichiometry working group at the National Center for Ecological Analysis and Synthesis (NCEAS), a center funded by the National Science Foundation (NSF), the University of California, and the State of California. The work was also supported by NSF grant DEB99-77047. We thank the staff of NCEAS for logistical support associated with our working group meetings. J. Cryan kindly provided access to unpublished results on delphacid phylogeny. We are indebted to C. Labandeira for an extensive and timely review of a previous draft. Two anonymous reviewers also provided helpful comments. We are especially grateful to $M$. Kyle for expediting several series of chemical analyses.

\section{Literature Cited}

Ackerly, D. D. 1999. Phylogeny and the comparative method in plant functional ecology. Pages 391-413 in M. Press, J. D. Scholes, and M. G. Barker, eds. Physiological plant ecology. Blackwell Scientific, Oxford.

Andersen, T., and D. O. Hessen. 1991. Carbon, nitrogen, and phosphorus content of freshwater zooplankton. Limnology and Oceanography 36:807-814.
Baudouin-Cornu, P., Y. Surdin-Kerjan, P. Marlière, and D. Thomas. 2001. Molecular evolution of protein atomic composition. Science (Washington, D.C.) 293:297-300.

Bernays, E. A. 1986. Diet-induced head allometry among foliage-chewing insects and its importance for graminivores. Science (Washington, D.C.) 231:495-497.

Berner, R. A. 1994. GEOCARB II: a revised model of atmospheric $\mathrm{CO}_{2}$ over Phanerozoic time. American Journal of Science 294:56-91.

1998. The carbon cycle and $\mathrm{CO}_{2}$ over Phanerozoic time: the role of land plants. Philosophical Transactions of the Royal Society of London B, Biological Sciences 353:75-81.

Bezemer, T. M., and T. H. Jones. 1998. Plant-herbivore interactions in elevated atmospheric $\mathrm{CO}_{2}$ : quantitative analyses and guild effects. Oikos 82:212-222.

Blackburn, T. M., and K. J. Gaston. 1998. Some methodological issues in macroecology. American Naturalist 151:68-83.

Bonnot, G. 1986. Les particularités de la nutrition des insectes parasites. Pages 227-240 in C. L. Legner et al., eds. La nutrition des crustacés et des insectes. Centre National d'Etudes et de Recommandations sur la $\mathrm{Nu}$ trition et l'Alimentation, Paris.

Bourgoin, T. H., J. D. Steffen-Campbell, and B. C. Campbell. 1997. Molecular phylogeny of Fulgoromorpha (Insecta, Hemiptera, Auchenorrhyncha). The enigmatic Tettigometridae: evolutionary affiliations and historical biogeography. Cladistics 13:207-224.

Bowers, M. D., N. E. Stamp, and E. D. Fajer. 1991. Factors affecting calculation of nutritional indices for foliagefed insects: an experimental approach. Entomologia Experimentalis et Applicata 61:101-116.

Burmester, T., H. C. Massey, Jr., S. O. Zakharkin, and H. Benes. 1998. The evolution of hexamerins and the phylogeny of insects. Journal of Molecular Evolution 47: 93-108.

Cain, D. J., S. N. Luoma, and E. V. Axtmann. 1995. Influence of gut content in immature aquatic insects on assessments of environmental metal contamination. Canadian Journal of Fisheries and Aquatic Science 52: 2736-2746.

Cebrian, J. 1999. Patterns in the fate of production in plant communities. American Naturalist 154:449-468.

Cerling, T. E., J. R. Ehleringer, and J. M. Harris. 1998. Carbon dioxide starvation, the development of $\mathrm{C}_{4}$ ecosystems, and mammalian evolution. Philosophical Transactions of the Royal Society of London B, Biological Sciences 353:159-171.

Chan, M. S., and H. C. J. Godfray. 1993. Host-feeding strategies of parasitoid wasps. Evolutionary Ecology 7: 593-604.

Chapco, W., R. K. D. Martel, and W. R. Kuperus. 1997. 
Molecular phylogeny of North American band-winged grasshoppers (Orthoptera: Acrididae). Annals of the Entomological Society of America 90:555-562.

Chapco, W., W. R. Kuperus, and G. Litzenberger. 1999. Molecular phylogeny of melanopline grasshoppers (Orthoptera: Acrididae): the genus Melanoplus. Annals of the Entomological Society of America 92:617-623.

Chapman, R. F. 1982. The insects: structure and function. 3d ed. Harvard University Press, Cambridge, Mass.

Cook, A., and R. F. Denno. 1994. Planthopper/plant interactions: feeding behavior, plant nutrition, plant defense and host plant specialization. Pages 114-139 in R. F. Denno and T. J. Perfect, eds. Planthoppers: their ecology and management. Chapman \& Hall, New York.

Curtis, P. S., and X. Z. Wang. 1998. A meta-analysis of elevated $\mathrm{CO}_{2}$ effects on woody plant mass, form, and physiology. Oecologia (Berlin) 113:299-313.

DeMott, W. R., R. D. Gulati, and K. Siewertsen. 1998. Effects of phosphorus-deficient diets on the carbon and phosphorus balance of Daphnia magna. Limnology and Oceanography 43:1147-1161.

Denno, R. F., and W. F. Fagan. 2003. Might nitrogen limitation promote omnivory among carnivorous arthropods? Ecology (in press).

Denno, R. F., and M. S. McClure, eds. 1983. Variable plants and herbivores in natural and managed systems. Academic Press, New York.

Denno, R. F., C. Gratton, M. A. Peterson, G. A. Langellotto, D. L. Finke, and A. F. Huberty. 2002. Bottom-up forces mediate natural-enemy impact in a phytophagous insect community. Ecology 83:1443-1458.

Dietrich, C. H. 1999. The role of grasslands in the diversification of leafhoppers (Homoptera: Cicadellidae): a phylogenetic perspective. Pages 44-48 in C. Warwick, ed. Proceedings of the 15th North American Prairie Conference, Natural Areas Association, Bend, Oreg.

Dixon, A. F. G. 1998. Aphid ecology. Chapman \& Hall, London.

Dow, J. A. T. 1986. Insect midgut function. Advances in Insect Physiology 19:187-328.

Ehrlich, P. R., and P. H. Raven. 1964. Butterflies and plants: a study in coevolution. Evolution 18:586-608.

Ekart, D. D., T. E. Cerling, I. P. Montanez, and N. J. Tabor. 1999. A 400 million year carbon isotope record of pedogenic carbonate: implications for paleoatmospheric carbon dioxide. American Journal of Science 299:805-827.

Elser, J. J., and J. Urabe. 1999. The stoichiometry of consumer-driven nutrient recycling: theory, observations, and consequences. Ecology 80:745-751.

Elser, J. J., D. Dobberfuhl, N. A. MacKay, and J. H. Schampel. 1996. Organism size, life history, and N : P stoi- chiometry: towards a unified view of cellular and ecosystem processes. BioScience 46:674-684.

Elser, J. J., R. W. Sterner, E. Gorokhova, W. F. Fagan, T. A. Markow, J. B. Cotner, J. F. Harrison, S. E. Hobbie, G. M. Odell, and L. J. Weider. 2000a. Biological stoichiometry from genes to ecosystems. Ecology Letters 3: 540-550.

Elser, J. J., W. F. Fagan, R. F. Denno, D. R. Dobberfuhl, A. Folarin, A. Huberty, S. Interlandi, et al. 2000b. Convergent $\mathrm{N}: \mathrm{P}$ stoichiometry in freshwater and terrestrial food webs. Nature 408:578-580.

Endo, T., and A. Endo. 1994. Prey selection by a spider wasp, Batozonellus lacerticida (Hymenoptera: Pompilidae): effects of seasonal variation in prey species, size, and density. Ecological Research 9:225-235.

Fagan, W. F. 1997. Omnivory as a stabilizing feature of natural communities. American Naturalist 150:554-568.

Faith, D. P., and P. S. Cranston. 1991. Could a cladogram this short have arisen by chance alone? on permutation tests for cladistic structure. Cladistics 7:1-28.

Farrell, B. D., A. S. Sequeira, B. C. O’Meara, B. J. Normark, J. H. Chung, and B. H. Jordal. 2001. The evolution of agriculture in beetles (Curculionidae: Scolytinae and Platypodinae). Evolution 55:2011-2027.

Felsenstein, J. 1985. Phylogenies and the comparative method. American Naturalist 125:1-15.

Finke, D. L., and R. F. Denno. 2002. Intraguild predation diminished in complex-structured vegetation: implications for prey suppression. Ecology 83:643-652.

Fox, L. R., and B. J. Macauley. 1977. Insect grazing on eucalyptus in response to variation in leaf tannins and nitrogen. Oecologia (Berlin) 29:145-162.

Furrer, S., and P. I. Ward. 1995. Differential nutrient extraction in the funnel-web spider Agelena labyrinthica. Physiological Entomology 20:18-22.

Greenwood, E. A. N. 1976. Nitrogen stress in plants. Advances in Agronomy 28:1-35.

Hagen, K. S. 1986. Nutritional ecology of terrestrial predators. Pages 533-577 in F. Slansky and J. G. Rodriguez, eds. Nutritional ecology of insects, mites, spiders, and related invertebrates. Wiley, New York.

Harvey, P. H., and M. D. Pagel. 1991. The comparative method in evolutionary biology. Oxford series in ecology and evolution. Oxford University Press, Oxford.

Heimpel, G. E., J. A. Rosenheim, and D. Kattari. 1997. Adult feeding and lifetime reproductive success in the parasitoid Aphytis melinus. Entomologia Experimentalis et Applicata 83:305-315.

Henry, T. J. 1997. Phylogenetic analysis of family groups within the infraorder Pentatomomorpha (Hemiptera: Heteroptera), with emphasis on the Lygaeoidea. Annals of the Entomological Society of America 90:275-301.

Hodge, M. A. 1999. The implications of intraguild pre- 
dation for the role of spiders in biological control. Journal of Arachnology 27:351-362.

Hopkin, S. P. 1997. Biology of springtails. Oxford University Press, Oxford.

Jackson, D. M., and K. M. Kester. 1996. Effects of diet on longevity and fecundity of the spined stilt bug, Jalysus wickhami. Entomologia Experimentalis et Applicata 80: 421-425.

Jervis, M. A., and N. A. C. Kidd. 1986. Host-feeding strategies in hymenopteran parasitoids. Biological Review 61: 395-434.

Knowles, L. L., and D. Otte. 2000. Phylogenetic analysis of montane grasshoppers from western North America (genus Melanoplus, Acrididae: Melanoplinae). Annals of the Entomological Society of America 93:421-431.

Krassilov, V. A., and A. P. Rasnitsyn. 1997. Pollen in the guts of Permian insects: first evidence of pollinvory and its evolutionary significance. Lethaia 29:369-372.

Kristensen, N. P. 1991. Phylogeny of extant hexapods. Pages 125-140 in I. D. Nauamnn, P. B. Crane, J. F. Lawrence, E. S. Nielsen, J. P. Spradberry, R. W. Taylor, M. J. Whitten, and M. J. Littlejohn, eds. The insects of Australia: a textbook for students and research workers. $2 \mathrm{~d}$ ed. CSIRO, Melbourne University Press, Melbourne.

Kristensen, N. P., and A. W. Skalski. 1999. Phylogeny and palaeontology. Pages 7-25 in N. P. Kristensen, ed. Lepidoptera, moths and butterflies. Vol. 1. Evolution, systematics, and biogeography. de Gruyter, Hawthorne, N.Y.

Kukalová-Peck, J., and J. F. Lawrence. 1993. Evolution of the hind wing in Coleoptera. Canadian Entomologist 125:181-258.

Labandeira, C. C. 1997. Permian pollen eating. Science (Washington, D.C.) 277:1421-1423.

. 1998. How old is the flower and the fly? Science (Washington, D.C.) 280:57-59.

Labandeira, C. C., and J. J. Sepkoski. 1993. Insect diversity in the fossil record. Science (Washington, D.C.) 261: 310-315.

Labandeira, C. C., D. L. Dilcher, D. R. Davis, and D. L. Wagner. 1994. 97-million years of angiosperm-insect association-paleobiological insights into the meaning of coevolution. Proceedings of the National Academy of Sciences of the USA 91:12278-12282.

Lawrence, J. F., and A. F. Newton. 1982. Evolution and classification of beetles. Annual Review of Ecology and Systematics 13:261-290.

Lemaire, C., and J. Minet. 1999. The Bombycoidea and their relatives. Pages 321-353 in N. P. Kristensen, ed. Lepidoptera, moths and butterflies. Vol. 1. Evolution, systematics, and biogeography. de Gruyter, Hawthorne, N.Y.
Lewis, J. G. E. 1981. The biology of centipedes. Cambridge University Press, Cambridge.

Li, D., and R. R. Jackson. 1997. Influence of diet on survivorship and growth in Portia fimbriata, an araneophagic jumping spider (Araneae: Salticidae). Canadian Journal of Zoology 75:1652-1658.

MacRae, I. V., and B. A. Croft. 1997. Intra- and interspecific predation by adult female Metaseiulus occidentalis and Typhlodromus pyri (Acari: Phytoseiidae) when provisioned with varying densities and ratios of Tetranychus urticae (Acari: Tetranychidae) and phytoseiid larvae. Experimental \& Applied Acarology 21:235-245.

Markow, T. A., B. Raphael, D. Dobberfuhl, C. M. Breitmeyer, J. J. Elser, and E. Pfeiler. 1999. Elemental stoichiometry of Drosophila and their hosts. Functional Ecology 13:78-84.

Marschner, H. 1995. Mineral nutrition of higher plants. Academic Press, London.

Mattson, W. J. 1980. Herbivory in relation to plant nitrogen content. Annual Review of Ecology and Systematics 11:119-161.

Mazer, S. J. 1998. Alternative approaches to the analysis of comparative data: compare and contrast. American Journal of Botany 85:1194-1199.

McAlpine, J. F. 1989. Phylogeny and classification of the Muscomorpha. In J. F. McAlpine and D. M. Wood, eds. Manual of Nearctic Diptera. Vol. 3. Research Branch, Agriculture Canada, Monograph 32:1397-1518.

McAlpine, J. F., B. V. Peterson, G. E. Shewell, H. J. Teskey, J. R. Vockeroth, and D. M. Wood, eds. 1981. Manual of Nearctic Diptera. Vol. 1. Research Branch, Agriculture Canada, Monographs 27. . 1987. Manual of Nearctic Diptera. Vol. 2. Research Branch, Agriculture Canada, Monographs 28.

McCann, K. S., and A. Hastings. 1997. Re-evaluating the omnivory-stability relationship in food webs. Proceedings of the Royal Society of London B, Biological Sciences 264:1249-1254.

McNeill, S., and T. R. E. Southwood. 1978. The role of nitrogen in the development of insect/plant relationships. Pages 77-98 in J. S. Harborne, ed. Aspects of plant and animal coevolution. Academic Press, London.

Mitchell, A., C. Mitter, and J. C. Regier. 2000. More taxa or more characters revisited: combining data from nuclear protein-encoding genes for phylogenetic analyses of Noctuoidea (Insecta: Lepidoptera). Systematic Biology 49:202-224.

Mitter, C., B. Farrell, and B. M. Wiegmann. 1988. The phylogenetic study of adaptive zones: has phytophagy promoted insect diversification? American Naturalist 132:107-128.

Moen, R., Y. Cohen, and J. Pastor. 1998. Linking moose 
population and plant growth models with a moose energetics model. Ecosystems 1:1-13.

Nielsen, S. L., S. Enríquez, C. M. Duarte, and K. SandJensen. 1996. Scaling maximum growth rates across photosynthetic organisms. Functional Ecology 10:167-175.

Nyffeler, M. 1999. Prey selection of spiders in the field. Journal of Arachnology 27:317-324.

Opell, B. D. 1998. Economics of spider orb-webs: the benefits of producing adhesive capture thread and recycling silk. Functional Ecology 12:613-624.

Otte, D., and P. Nasrecki. 1997. Orthoptera species online. http://viceroy.eeb.uconn.edu/Orthoptera.

Oxford, G. S. 1998. Guanine as a colorant in spiders: development, genetics, phylogenetics and ecology. Pages 121-131 in P. A. Selden, ed. Proceedings of the 17th European Colloquium of Arachnology, Edinburgh 1997. British Arachnological Society, Burnham Beeches, Bucks, U.K.

Pastor, J., R. J. Naiman, B. Dewey, and P. McInnes. 1988. Moose, microbes, and the boreal forest. BioScience 38 : 770-776.

Peakall, D. B. 1971. Conservation of web proteins in the spider, Araneus diadematus. Journal of Experimental Zoology 176:257-264.

Peñuelas, J., and R. Matamala. 1990. Changes in N and S leaf content, stomatal density, and specific leaf areas of 14 plant species during the last three centuries of $\mathrm{CO}_{2}$ increase. Journal of Experimental Botany 41:1119-1124.

Perez, D. V., S. de Alcantara, R. J. Arruda, and N. D. A. Meneghelli. 2001. Comparing two methods for soil carbon and nitrogen determination using selected Brazilian soils. Communications in Soil Science and Plant Analysis 32:295-309.

Pitnick, S., G. S. Spicer, and T. Markow. 1997. Phylogenetic examination of female incorporation of ejaculate in Drosophila. Evolution 51:833-845.

Polis, G. A. 1991. Complex trophic interactions in deserts: an empirical critique of food-web theory. American Naturalist 138:123-155.

Reynolds, S. E., S. F. Nottingham, and A. E. Stephens. 1985. Food and water economy and its relation to growth in fifth-instar larvae of the tobacco hornworm, Manduca sexta. Journal of Insect Physiology 31:119-127.

Riechert, S. E., and J. M. Harp. 1986. Nutritional ecology of spiders. Pages 645-672 in F. Slansky and J. G. Rodriguez, eds. Nutritional ecology of insects, mites, spiders, and related invertebrates. Wiley, New York.

Rosenheim, J. A., L. R. Wilhoit, and C. A. Armer. 1993. Influence of intraguild predation among generalist insect predators on the suppression of an herbivore population. Oecologia (Berlin) 96:439-449.

Russo, C. A. M., N. Takezaki, and M. Nei. 1995. Molecular phylogeny and divergence times of drosophilid species. Molecular Biology and Evolution 12:391-404.

Schuh, R. T. 1976. Pretarsal structure in the Miridae (Hemiptera) with a cladistic analysis of relationships within the family. American Museum Novitates 2601:1-39.

Schuh, R. T., and J. A. Slater. 1995. True bugs of the world (Hemiptera: Heteroptera): classification and natural history. Cornell University Press, Ithaca, N.Y.

Sidor, C. A. 2001. Simplification as a trend in synapsid cranial evolution. Evolution 55:1419-1442.

Slansky, F., and P. Feeny 1977. Stabilization of the rate of nitrogen accumulation by larvae of the cabbage butterfly on wild and cultivated plants. Ecological Monographs 47:209-228.

Sokal, R. R., and F. J. Rohlf. 1995. Biometry. 3d ed. W. H. Freeman, New York.

Southwood, T. R. E. 1973. The insect/plant relationship —an evolutionary perspective. In H. F. van Emden, ed. Insect/plant relationships. Symposium of the Royal Entomological Society of London 6:3-30.

Sterner, R. W., and J. J. Elser. 2002. Ecological stoichiometry. Princeton University Press, Princeton, N.J.

Sterner, R. W., and K. L. Schulz. 1998. Zooplankton nutrition: recent progress and reality check. Aquatic Ecology 32:1-19.

Strong, D. R., J. H. Lawton, and T. R. E. Southwood. 1984. Insects on plants. Harvard University Press, Cambridge, Mass.

Swofford, D. L. 2001. PAUP^: phylogenetic analysis using parsimony (and other methods). Version 4.0b6. Sinauer, Sunderland, Mass.

Thompson, S. N. 1999. Nutrition and culture of entomophagous insects. Annual Review of Entomology 44: 561-592.

Timmermann, S., and M. R. Berenbaum. 1999. Uric acid deposition in larval integument of black swallowtails and speculation on its possible functions. Journal of the Lepidopterists' Society 53:104-107.

Toft, S. 1999. Prey choice and spider fitness. Journal of Arachnology 27:301-307.

Toft, S., and D. H. Wise. 1999a. Behavioral and physiological responses of a generalist predator to single- and mixed-species diets of different quality. Oecologia (Berlin) 119:198-207.

. 1999b. Growth, development, and survival of a generalist predator fed single- and mixed-species diets of different quality. Oecologia (Berlin) 119:191-197.

Uetz, G. W., J. Bischoff, and J. Raver. 1992. Survivorship of wolf spiders (Lycosidae) reared on different diets. Journal of Arachnology 20:207-211.

Urabe, J., and Y. Watanabe. 1992. Possibility of $\mathrm{N}$ or P limitation for planktonic cladocerans: an experimental test. Limnology and Oceanography 37:244-251. 
Vrede, T., T. Andersen, and D. O. Hessen. 1998. Phosphorus distribution in three crustacean zooplankton species. Limnology and Oceanography 44:225-229.

Watson, M. E., and T. L. Galliher. 2001. Comparison of Dumas and Kjeldahl methods with automatic analyzers on agricultural samples under routine rapid analysis conditions. Communications in Soil Science and Plant Analysis 32:2007-2019.

Wheeler, W. C., M. Whiting, Q. D. Wheeler, and J. M. Carpenter. 2001. The phylogeny of the extant hexapod orders. Cladistics 17:113-169.

White, T. C. R. 1993. The inadequate environment: nitrogen and the abundance of animals. Springer, New York.
Yasuda, H., and N. Ohnuma. 1999. Effect of cannibalism and predation on the larval performance of two ladybird beetles. Entomologia Experimentalis et Applicata 93: 63-67.

Yeates, D. K., and B. M. Wiegmann. 1999. Congruence and controversy: toward a higher-level phylogeny of Diptera. Annual Review of Entomology 44:397-428.

Yin, X. W. 1993. Variation in foliar nitrogen concentration by forest type and climatic gradients in North America. Canadian Journal of Forest Research 23:1587-1602.

Associate Editor: Mark E. Ritchie 
Copyright $\odot 2002$ EBSCO Publishing 